\title{
HUBUNGAN ANTARA STATUS GIZI DENGAN LAMA RAWAT INAP PADA PASIEN DIABETES MELITUS TIPE 2 DI INSTALASI RAWAT INAP I ILMU PENYAKIT DALAM RSUD Dr. SAIFUL ANWAR MALANG
}

\author{
Savitri Pramesti Santoso*® ${ }^{*}$ Nur Rahma Desiana*, Inggita Kusumastuty ${ }^{*}$ Ida Restyani ${ }^{* *}$
}

\begin{abstract}
Abstrak
Salah satu permasalahan yang dihadapi oleh rumah sakit yaitu malnutrisi. Status gizi yang kurang pada pasien dapat memunculkan length of stay yang lebih lama daripada pasien yang memiliki kondisi status gizi baik. Penelitian ini bertujuan mengetahui hubungan antara status gizi dengan lama rawat inap pada pasien DM tipe 2 di IRNA I RSUD Dr. Saiful Anwar Malang. Metode penelitian yaitu dengan crosssectional menggunakan metode purposive sampling dan didapatkan sebanyak 30 responden Pengukuran status gizi dilakukan dengan menggunakan Indeks Massa Tubuh (IMT) dan Lingkar Lengan Atas (LILA). Hasil menunjukkan tidak ada hubungan yang signifikan antara status gizi dengan lama rawat (nilai $p=$ $0,537)$. Disimpulkan bahwa tidak ada hubungan antara status gizi dengan lama rawat inap pasien DM Tipe 2 di IRNA I RSUD Dr Saiful Anwar Malang.
\end{abstract}

Kata Kunci: diabetes melitus tipe 2, IRNA ilmu penyakit dalam, lama rawat inap, status gizi.

\section{RELATIONSHIP BETWEEN NUTRITIONAL STATUS WITH LENGHT OF STAY OF TYPE 2 DIABETES MELLITUS PATIENTS IN INPATIENT INSTALLATION I OF INTERNAL MEDICINE Dr. SAIFUL ANWAR PUBLIC HOSPITAL MALANG}

\begin{abstract}
One of the nutrition problem in the hospital is malnutrition. Malnutrition status in patients can take a longer length of stay compared to patiens with a good nutritional status. This research aims to find out a relationship between nutritional status and lenght of stay to patients with type 2 diabetes mellitus in inpatient installation I of internal medicine Dr. saiful anwar public hospital Malang. This was a crosssectional study which used purposive sampling that obtained 30 respondents. The anthropometric measurements used in this study are Body Mass Index (BMI) and mid-arm circumference. The result showed that nutritional status was not significantly related with lenght of stay $p=0,539$. To be concluded, there was no significant relationship between nutritional status and lenght of stay of patients with type 2 diabetes meliitus in inpatient installation I of internal medicine Dr. saiful anwar public hospital Malang.
\end{abstract}

Keywords: diabetes mellitus tipe 2, inpatient installation I of internal medicine, lenght of stay, nutritional status.

* Program Studi Profesi Dietisien, Fakultas Kedokteran, Universitas Brawijaya

${ }^{* *}$ Instalasi Gizi RSUD Dr Saiful Anwar Malang

E-mail: savitripramesti11@gmail.com 


\section{Pendahuluan}

Salah satu permasalahan yang dihadapi rumah sakit dalam upaya penyembuhan pasien yaitu malnutrisi. Malnutrisi dapat timbul sebelum pasien memasuki lingkungan rumah sakit, yang dapat disebabkan karena penyakit yang diderita, bisa juga dari asupan makan pasien yang tidak memenuhi kebutuhan dan selama pasien dalam proses rawat inap. Faktor yang menyebabkan malnutrisi di antaranya makanan rendah gizi, infeksi parah yang berulang dan masyarakat dengan ekonomi kurang mampu. Angka malnutrisi yang tinggi tersebut merata di rumah sakit yang terkait dengan penyakit dan golongan masyarakat yang beragam. ${ }^{1}$ Hasil penelitian menunjukkan bahwa pasien yang memiliki status gizi yang kurang baik (malnutrisi) memiliki length of stay yang lebih panjang daripada pasien dengan status gizi baik. ${ }^{2}$

Penyakit DM tipe 2 adalah penyakit yang berisiko memunculkan kondisi malnutrisi, sehingga bila dibarengi dengan komplikasi maka akan memperparah kondisi dan berdampak pada malnutrisi. Pada kondisi tersebut perlu ada perawatan lebih lanjut terutama dari asuhan gizi untuk memperbaiki kondisi pasien. 3,4 Prevalensi DM tipe 2 tahun 2018 di Jawa Timur sebesar 2,6\% meningkat dari 2,1\% tahun 2013, dan di Malang sebesar 2,8\% meningkat dari 2,3\% dan pada tahun 2007 yaitu sebesar $6,8 \%$ di Jawa Timur. 5,6

Status gizi dapat mempengaruhi kondisi kesehatan pasien, pengobatan dari kesakitan atau proses aktifitas pada pasien, serta mempengaruhi munculnya infeksi dan pengobatan dari infeksi. Kondisi malnutrisi ditemukan pada sekitar 30\% pasien yang mendapat perawatan di rumah sakit dan berkaitan dengan kondisi klinis, morbiditas, mortalitas, biaya saat perawatan serta quality of life yang buruk pada pasien. ${ }^{7}$ Oleh karena itu, perlu adanya penelitian untuk mengetahui hubungan antara status gizi dengan lama rawat inap pada pasien DM tipe 2 di RSUD Dr Saiful Anwar Malang.

\section{Bahan dan Metode}

\section{Desain Penelitian}

Penelitian ini bersifat observasional untuk mengetahui hubungan antara status gizi saat masuk ke rumah sakit dengan lama rawat inap pada pasien DM tipe 2 di IRNA I IImu Penyakit Dalam (IPD) RSUD Dr Saiful Anwar Malang. Desain penelitian adalah cross-sectional. Penelitian ini telah mendapatkan izin etik dari Komisi Etik RSUD Dr Saiful Anwar Malang dengan nomor 400/082/K.3/302/2020.

\section{Sumber Data}

Data yang diperoleh terbagi menjadi 2 yaitu primer dan sekunder. Data primer yaitu status gizi menurut Lingkar Lengan Atas (LILA) dan Indeks Massa Tubuh (IMT) dengan pengukuran langsung, serta observasi lama rawat inap pasien.

Data sekunder yang digunakan yaitu riwayat penyakit pasien, data umum pasien (jenis kelamin dan umur pasien), riwayat merokok, serta data biokimia pasien (GDP, GD2JPP, $\mathrm{HbA} 1 \mathrm{c}$, dan $\mathrm{Hb}$ ) dari rekam medis pasien.

\section{Populasi/Sampel/Subjek Penelitian}

Sampel untuk penelitian ditentukan secara purposive sampling yang memenuhi kriteria inklusi dan kategori eksklusi tidak digunakan dalam peelitian. Kriteria inklusi yaitu pasien merupakan pasien DM tipe 2 baru yang masuk ketika hari pengamatan mulai dilakukan; pasien berada di IRNA I IPD;dan pasien dewasa yang menderita DM tipe 2 dengan berbagai komplikasi (infeksi maupun penyakit tidak menular). Kriteria eksklusi yaitu pasien bukan berada di ruang IRNA I RSUD Dr Saiful Anwar Malang; pasien meninggal ketika hari pengamatan berlangsung selama 7 hari. 
Penelitian ini mendapatkan 30 responden yang bersifat analitik deskriptif. Variabel independen yaitu status gizi pasien DM tipe 2 dan variabel dependen yaitu lama rawat inap pasien DM tipe 2.

\section{Teknik Pengumpulan Data}

Pengambilan data yaitu dilakukan di ruang rawat inap I IPD dan dilakukan pengecekan rekam medis untuk melihat status gizi pasien serta membuat daftar responden yang masuk kriteria eksklusi dan inklusi. Pasien dipilih berdasarkan pengukuran antropometri (IMT dan LILA) yang tergolong dalam kategori kurang, normal, dan berlebih. Status gizi terbagi menjadi kurang, normal, dan berlebih sesuai dengan indikator status gizi dari \%LILA dan IMT. Untuk IMT yaitu $<18,5 \mathrm{~kg} / \mathrm{m}^{2}$ untuk status gizi kurang, normal yaitu $18,5-22,9 \mathrm{~kg} /$ $\mathrm{m}^{2}$, dan berlebih bila $\geq 23 \mathrm{~kg} / \mathrm{m}^{2} .8$ Untuk $\%$ LILA yaitu bila kurang $\leq 90 \%$ standar, normal yaitu $91-109 \%$ standar, dan berlebih bila $\geq$ $110 \%$ standar. ${ }^{8}$ Setelah itu, pasien yang terpilih akan menjadi responden penelitian dan dilakukan pengamatan selama tujuh hari terkait antropometri, biokimia, asupan makan, dan riwayat penyakit pasien lalu dikaitkan dengan lama rawat inap pasien di IRNA I IPD RSUD Dr Saiful Anwar Malang.

\section{Teknik Analisis Data}

Data dianalisis dengan software SPSS 16.0 untuk menganalisis secara univariat dan bivariat. Uji yang dilakukan yaitu uji Pearson untuk data yang terdistribusi normal dan Spearman untuk data yang tidak terdistribusi normal.

\section{Hasil}

Karakteristik Responden

Berdasarkan data didapatkan karakteristik responden (Tabel 1) yang sebagian besar responden berjenis kelamin perempuan, usia responden 45-60 tahun, dengan lama rawat inap 3-7 hari.

Tabel 1. Karakteristik responden

\begin{tabular}{lll}
\hline \multicolumn{1}{c}{ Karakteristik } & $\mathrm{n}$ & $\%$ \\
\hline $\begin{array}{l}\text { Jenis Kelamin } \\
\text { Laki-laki }\end{array}$ & 13 & 43,3 \\
$\quad$ Perempuan & 17 & 56,7 \\
Usia & & \\
$\quad<45$ tahun & 2 & 6,7 \\
$\quad 45-60$ tahun & 19 & 63,3 \\
$\quad>60$ tahun & 9 & 30 \\
Lama Rawat Inap & & \\
$\quad 3-<5$ hari & 4 & 13,3 \\
$\quad$ 5-7 hari & 26 & 86,7 \\
Lama Menderita DM tipe 2 & & \\
$\quad<5$ tahun & 14 & $46,7 \%$ \\
$\quad \begin{array}{l}\text { P tahun } \\
\quad \text { Gangguan Ginjal }\end{array}$ & 16 & $53,3 \%$ \\
$\quad$ Gangguan jantung & 17 & 56,7 \\
$\quad$ Lain-lain & 5 & 16,7 \\
\hline
\end{tabular}


Lanjutan Tabel 1. Karakteristik responden

\begin{tabular}{lll}
\hline \multicolumn{1}{c}{ Karakteristik } & $\mathrm{n}$ & $\%$ \\
\hline Anggota Keluarga Perokok Aktif & & \\
$\quad$ Ya & 18 & 60 \\
$\quad$ Tidak & 12 & 40 \\
Glukosa Darah Puasa (GDP) & & \\
$\quad$ Normal $(<100)$ & 3 & 14,3 \\
$\quad$ Tinggi $(\geq 100)$ & 18 & 85,7 \\
HbA1c & & \\
$\quad$ Normal $(<6,5)$ & 0 & 0 \\
$\quad$ Tinggi $(\geq 6,5)$ & 19 & 100 \\
GD2JPP (Glukosa Darah 2 Jam Post Prandial) & \\
$\quad$ Normal $(<140)$ & 2 & 10 \\
$\quad$ Tinggi $(\geq 140)$ & 18 & 90 \\
Hemoglobin (Hb) & & \\
$\quad$ Rendah $(<12$ g/l) & 25 & 83,3 \\
$\quad$ Normal & 5 & 16,7 \\
Persen Rata-Rata Asupan Makan & & \\
$\quad$ Sangat kurang $(<50 \%)$ & 14 & 46,7 \\
$\quad$ Kurang (50-<75\%) & 11 & 36,7 \\
$\quad$ Tidak kurang $(\geq 75 \%)$ & 5 & 16,7 \\
\hline
\end{tabular}

Tabel 2. Persebaran kategori status gizi responden

\begin{tabular}{lcc}
\hline \multicolumn{1}{c}{ Kategori Status Gizi } & Jumlah $(\mathrm{n})$ & $\%$ \\
\hline Kurang & 22 & 20 \\
Normal & 6 & 73,3 \\
Berlebih & 2 & 6,7 \\
\hline
\end{tabular}

Selain itu, pasien memiliki riwayat penyakit DM tipe 2 selama $\geq 5$ tahun dengan bawaan penyakit penyerta sebagian besar gangguan ginjal dan terdapat keluarga yang merokok. Didapatkan sebanyak $85,7 \%$ pasien saat awal masuk rumah sakit (MRS) memiliki glukosa darah puasa dalam rentang yang tinggi ( $\geq 100 \mathrm{mg} / \mathrm{dl}$ ). Nilai hemoglobin A1c (HbA1c) pasien yaitu $100 \%$ dalam rentang yang tinggi $(\geq 6,5 \%)$. Kadar gula darah 2 jam post prandial (GD2JPP) pada $90 \%$ responden memiliki nilai yang tinggi saat MRS ( $\geq 140 \mathrm{mg} /$ dl) dan hemoglobin responden yaitu cenderung rendah sebanyak 25 responden $(83,3 \%)$. Untuk persen rata-rata asupan makan yaitu $46,7 \%$ sangat kurang, $36,7 \%$ yaitu kurang, dan tidak kurang 16,7\%,

Hubungan antara Status Gizi Pasien dengan Lama Rawat Inap

Data menunjukkan sebagian besar responden berdasarkan pengukuran LILA untuk mengetahui status gizinya yaitu sebanyak 76,7\%. Untuk kategori IMT sebagian besar memiliki IMT yang kurang sebanyak $57,1 \%$. Persentase LILA sebagian besar responden memiliki nilai persentase LILA yang kurang (78,3\%) (Tabel 2). Selain itu, hasil uji Pearson menunjukkan tidak ada hubungan yang signifikan baik dari status gizi IMT dan persen LILA dengan lama rawat inap (Tabel 3). 
Tabel 3. Hubungan antara status gizi dengan lama rawat inap

\begin{tabular}{lcc}
\hline \multicolumn{1}{c}{ Variabel } & $\mathrm{n}$ & $\mathrm{P}$ \\
\hline $\begin{array}{l}\text { Status Gizi } \\
\text { Lama Rawat Inap }\end{array}$ & 7 & $0,539^{*}$ \\
\hline
\end{tabular}

* Uji Spearman (nilai p > 0,05)

\section{Pembahasan}

\section{Karakteristik Responden}

Karakteristik responden sebagian besar berjenis kelamin perempuan yang berusia 45 60 tahun, dengan lama rawat inap 3-7 hari. Responden memiliki riwayat penyakit DM Tipe 2 selama $\geq 5$ tahun dengan bawaan penyakit penyerta sebagian besar gangguan ginjal dan terdapat keluarga yang merokok. Hal tersebut sejalan dengan pernyataan Trisnawati dan Setyorogo (2013) serta Fatimah (2015) yaitu kejadian diabetes mellitus tipe 2 lebih banyak terjadi pada perempuan dibandingkan dengan laki-laki, kondisi tersebut yaitu karena terkait fisik perempuan yang memiliki risiko terkait IMT yang lebih besar. 9,10

Selain itu, faktor umur juga berpengaruh pada kondisi DM tipe 2. Kelompok umur $>45$ tahun memiliki risiko mengalami DM tipe 2 lebih tinggi bila dibandingkan dengan umur 45 tahun ke bawah. Peningkatan umur dapat meningkatkan kejadian DM tipe 2 berkaitan dengan terjadinya intoleransi glukosa dan adanya proses penuaan yang menyebabkan berkurangnya kemampuan sel beta pankreas untuk memproduksi insulin. Pada individu yang berusia lebih tua terdapat penurunan aktivitas mitokondria pada sel-sel otot sebesar 35\%. Kondisi perokok aktif maupun perokok pasif yang terpapar asap rokok akan berisiko mengalami DM tipe 2 karena asap rokok dapat meningkatkan kadar gula darah. 9,10 Hal ini sejalan dengan pernyataan Kurniawaty dan Yanita (2016) bahwa umur $\geq 45$ tahun dapat meningkatkan kejadian DM Tipe 2 karena penuaan menyebabkan menurunnya sensitivitas insulin dan menurunnya fungsi tubuh pada metabolisme glukosa. Orang berusia $\geq 45$ tahun mempunyai risiko 9 kali untuk terjadinya DM Tipe 2 dibandingkan dengan yang berumur kurang dari 45 tahun, selain itu memiliki kebiasaan merokok memiliki risiko 3 kali terjadinya DM Tipe 2 dibandingkan dengan orang yang tidak memiliki kebiasaan merokok. ${ }^{11}$

Lama rawat inap yang terlalu panjang akan menimbulkan kerugian antara lain menambah beban biaya perawatan pasien, mengurangi cakupan pelayanan kesehatan rumah sakit, dan menjadi pemborosan bagi rumah sakit, serta dapat mempengaruhi perubahan berat badan dan kejadian malnutrisi bagi pasien. Malnutrisi dapat muncul ketika pasien belum mendapatkan proses perawatan karena kondisi penyakitnya atau asupan zat gizi yang tidak cukup, akan tetapi malnutrisi dapat muncul selama pasien dalam proses rawat inap. Malnutrisi dapat terjadi antara $40-60 \%$ pada pasien rawat inap dengan penyakit akut, yang pada awalnya datang tanpa terdapat permasalahan gizi dan kemudian terjadi penurunan status gizi dalam kurun waktu tiga minggu secara perlahan. ${ }^{12}$

Kadar puasa (GDP), gula darah 2 jam post prandial (GD2JPP), dan HbA1c yaitu hemoglobin yang terikat dengan glukosa pada penderita DM menunjukkan cenderung meningkat dibandingkan dengan kondisi tidak mengalami DM. Kondisi penderita DM memiliki risiko yang lebih tinggi untuk mengalami masalah kesehatan lain dan terjadi penurunan kualitas hidup..$^{13}$ Selain itu, ada pengaruh status gizi terkait dengan komplikasi penyakit yang ditimbulkan oleh penderita DM. 
Komorbiditas penyakit DM berhubungan erat dengan kondisi status gizi yang kurang. Penelitian oleh Yusnitasari dkk. (2015) menunjukkan bahwa penyakit DM dengan komplikasi tuberkulosis (TB) akan memperparah kualitas hidup dan status gizi akan menurun sehingga berpengaruh pada kesembuhan penyakit TB. ${ }^{14}$ Pada responden didapatkan kondisi biokimia gula darah dan hemoglobin dalam kondisi abnormal (Tabel 1). Kondisi biokimia yang tidak terkontrol dapat terjadi pada seseorang yang kurang menjalani pola hidup yang sehat seperti kurang olahraga, asupan makan yang tidak terjaga, serta manajemen stres yang tidak baik. Hal ini bila tidak ditangani dengan baik maka akan menimbulkan komplikasi dari diabetes melitus tipe 2 seperti gagal ginjal dan penyakit jantung. Jadi, dengan penanganan asuhan gizi diharapkan bisa memperbaiki kondisi pasien terutama nilai biokimia gula darah. ${ }^{15}$

Asupan zat gizi yang cukup untuk pasien sangat diperlukan dalam mencegah penurunan status gizi selama menjalani proses perawatan di rumah sakit. Perubahan asupan zat gizi tersebut dapat dikategorikan menjadi dua, yaitu peningkatan dan penurunan. Asupan zat gizi dikategorikan mengalami peningkatan apabila terjadi perubahan antara kategori asupan zat gizi pada awal dan akhir yaitu dimulai kategori tidak cukup menjadi cukup maupun dari cukup yang tetap menjadi cukup. Namun, asupan zat gizi dikategorikan mengalami penurunan apabila terjadi perubahan kategori asupan pada zat gizi awal dan akhir yaitu dimulai dari kategori cukup menjadi tidak cukup, maupun dari tidak cukup tetap menjadi tidak cukup. ${ }^{12}$

Berdasarkan rata-rata asupan selama pasien dirawat yaitu sebagian besar dalam kondisi sangat kurang (Tabel 1). Pasien yang mengalami status gizi kurang akan diberikan asuhan gizi untuk memperbaiki kondisinya.
Hal ini melalui pengelolaan DM yaitu meliputi edukasi, terapi gizi medis, latihan jasmani, dan terapi farmakologis. Terapi gizi yang dilakukan pada pasien DM merupakan langkah pertama dalam manajemen DM. Pengelolaan yang tepat dan berhasil diharapkan akan memberikan asuhan gizi yang berkualitas. Berdasarkan penelitian yang dilakukan di RSPAD Gatot Soebroto Jakarta terkait asupan makan dan asuhan gizi yaitu memiliki hubungan yang signifikan dari energi, protein, lemak, dan karbohidrat responden. Oleh karena itu, asupan makan yang sesuai kebutuhan bisa memperbaiki kondisi pasien terkait biokimia terutama gula darah, kondisi fisik klinis pasien, dan status gizi pasien. ${ }^{16,17}$

Hubungan antara Status Gizi dengan Lama Rawat Inap

Pada penelitian ini status gizi pasien diukur menggunakan LILA yang dilakukan pada sebagian besar pasien $(76,7 \%)$. Data reponden yang memiliki status gizi kurang sebanyak 73,3\% (Tabel 2). Hasil uji Spearman didapatkan nilai $p=0,539$, menunjukkan tidak terdapat hubungan yang signifikan antara status gizi dengan lama rawat inap (Tabel 3). Hal tersebut karena sebelum pasien masuk rumah sakit sudah memiliki asupan makan yang kurang baik, sehingga dapat mempengaruhi status gizi yang ada ketika pasien masuk rumah sakit dan menjalani proses perawatan.

Sejalan dengan penelitian sebelumnya yaitu pasien yang awal masuk mempunyai status gizi kurang menurut IMT dan selama perawatan asupan energi juga kurang, mempunyai risiko 3,05 kali lebih besar untuk pulang dalam keadaan tidak sembuh. Selain itu, status gizi awal menurut IMT maupun LILA bukan merupakan faktor risiko yang mempengaruhi lama rawat inap secara langsung. ${ }^{18,19}$ 
Berdasarkan hasil penelitian oleh Entika (2017) didapatkan status gizi tidak memiliki hubungan yang signifikan dengan terjadinya komplikasi pasien DM tipe 2. Hal ini karena adanya pengaruh lama sakit, umur, jenis kelamin, aktivitas fisik (olahraga), pola makan, dan pola hidup. Faktor yang dapat mempercepat maupun memperlambat adanya komplikasi seperti perilaku preventif dari penderita dalam menangani diabetes agar terhindar dari komplikasi jangka Panjang. ${ }^{20}$

Namun, menurut penelitian yang dilakukan oleh Nurlindayanti dkk. (2015) terkait status gizi dengan lama rawat inap pada pasien jantung menunjukkan adanya hubungan yang bermakna yaitu semakin seseorang memiliki status gizi baik, maka lama rawat inap akan semakin pendek, dengan uji Chi-square dengan nilai $p=0,015$ dan $R R=1,563$ yang berarti bahwa pasien yang terkena penyakit jantung dengan status gizi kurang memiliki kemungkinan lama rawat inap 1,563 kali lebih panjang dibandingkan dengan kondisi pasien yang terkena penyakit jantung dengan status gizi baik. Hal ini menunjukkan bahwa peningkatan insiden malnutrisi pada pasien-pasien di rumah sakit akan meningkatkan lama rawat inap dan biaya perawatan. Selain itu, Pasien yang berisiko malnutrisi mempunyai masa rawat yang lebih panjang dibandingkan dengan yang tidak berisiko malnutrisi. ${ }^{21}$

Adanya kondisi pasien dengan perubahan asupan makan yang tidak terlalu signifikan namun dipulangkan lebih cepat karena kondisi pasien yang sudah membaik. Selain itu, faktor pengobatan bisa menjadi alasan pasien pulang lebih lama atau cepat dan status gizi kemungkinan bukan satusatunya indikator pasien memiliki rawat inap yang lama atau cepat, serta dipengaruhi kondisi pasien baik biokimianya maupun keadaan penyakit yang mulai membaik. Selain itu, dapat dipengaruhi oleh kelas perawatan yang berbeda dalam hal pengaturan ruang, fasilitas dan cara penyajian makanan yang mempengaruhi lama rawat inap pasien. ${ }^{18}$

\section{Kesimpulan}

Penelitian ini menyimpulkan bahwa tidak terdapat hubungan yang signifikan antara perubahan status gizi dengan lama rawat inap pada pasien diabetes mellitus tipe 2 di IRNA I RSUD Dr Saiful Anwar Malang

\section{Saran}

Perlu dilakukan penelitian lebih lanjut terkait asupan yang diberikan kepada pasien dengan menghitung kebutuhan masingmasing individu. Sebaiknya dilakukan pengukuran status gizi ketika akan keluar dari ruang perawatan. Melakukan pengambilan data asupan makanan selama 3 bulan terakhir, untuk mengetahui secara pasti kejadian malnutrisi yang dialami pasien dan untuk mempercepat proses penyembuhan.

\section{Daftar Pustaka}

1. Permatasari ME. Economic Burden of Disease Associated with Poor Nutrition Status (Malnutriton). Jakarta: BPJS Kesehatan. (Online). 2019. https:// persi.or.id/wp-content/uploads/2019/02/ PPT_Kebijakan_BPJS_Kesehatan_Maln utrisi_update4.pdf.

2. Meijers JMM, Schueren MAE, Schols JMGA, Soeters PB, Halfens RJG. Defining Malnutrition: Mission or Mission Imposible?. Nutrition. 2010; 26(4):432440.

3. Rosyada A., Trihandini I. Determinan Komplikasi Kronik Diabetes Melitus pada Lanjut Usia. Jurnal Kesehatan Masyarakat Nasional. 2013; 7(9): 395401. 
4. Hapsari PNF, Isfandiari MA. Hubungan Sosioekonomi dan Gizi dengan Risiko Tuberkulosis pada Penderita DM Tipe 2. Jurnal Berkala Epidemiologi. 2017; 5 (2):185-194.

5. RISKESDAS. Hasil Utama Riskesdas 2018 Provinsi Jawa Timur. Kementerian Kesehatan RI Badan Penelitian dan Pengembangan Kesehatan, 2018.

6. Wijayanti $P$, Sujuti $H$, Tritisari KP. Hubungan Pola Konsumsi Makanan Sumber Kalsium dan Magnesium dengan Kadar Kolesterol Total Pasien Diabetes Mellitus Tipe 2 di Poliklinik Penyakit Dalam RSU Dr. Saiful Anwar Malang. Majalah Kesehatan, 2014; 1 (2):102-111.

7. Darmojo T, Robbi, Rakhmadi A. Aplikasi Screening Gizi Menggunakan Metode Subjective Global Asessment. Diploma Thesis. Surakarta: Fakultas Komunikasi dan Informatika, Universitas Muhammadiyah Surakarta. 2018.

8. Handayani $D$, Anggraeny $\mathrm{O}$, Dini $\mathrm{CY}$, Kurniasari FN, Kusumastuty I, Tritisari KP, Murtiyani M, Erliana UD. Nutrition Care Process. Malang: $\quad \mathrm{G} \mathrm{r}$ a h a IImu. 2014.

9. Trisnawati SK dan Setyorogo S. Faktor Risiko Kejadian Diabetes MelitusTipe II di Puskesmas Kecamatan Cengkareng Jakarta Barat Tahun 2012. Jurnal IImiah Kesehatan. 2013; 5(1): 6-11.

10. Fatimah RN. Diabetes Melitus Tipe 2. Journal Majority. 2015; 4(5):93-101.

11. Kurniawaty $E$ dan Yanita B. FaktorFaktor yang Berhubungan dengan Kejadian Diabetes Mellitus Tipe II. Medical Journal of lampung University. 2016; 5(2):27-31.

12. Nurmala, Susetyowati, Budiningsari RD. Perubahan Asupan Zat Gizi Tidak Berpengaruh terhadap Lama Rawat Inap Pasien Dewasa di RSUP Dr. Sardjito Yogyakarta. Jurnal Gizi dan Dietetik Indonesia. 2016; 2(1):14-22.
13. Lathifah NL. Hubungan Durasi Penyakit dan Kadar Gula Darah dengan Kaluhan Subyektif Penderita Diabetes Melitus. Jurnal Berkala Epidemiologi. 2017; 5 (2):231-239.

14. Yusnitasari AS, Thaha ILM, Syafar M. Komorbiditas Diabetes Melitus Terhadap Manifestasi Klinik dan Kualitas Hidup pada Penderita Tuberkulosis Paru. Media Kesehatan Masyarakat Indonesia. 2015; 11(2):8691.

15. Wulandari $O$ dan Martini S. Perbedaan Kejadian KomplikasiPenderita Diabetes Melitus Tipe 2 Menurut Gula Darah Acak. Jurnal Berkala Epidemiologi. 2013; 1 (2):182-191.

16. Yunita, Asdie AH, Susetyowati. Pelaksanaan Proses Asuhan Gizi Terstandar (PAGT) terhadap Asupan Gizi dan Kadar Glukosa Darah Pasien Diabetes Melitus Tipe 2. Jurnal Gizi Klinik Indonesia, 2013, 10(2): 82-91

17. Kasim DA, Harikedua VT, Paruntu OL. Asupan Makanan, Status Gizi dan Lama Hari Rawat Inap Pada Pasien Penyakit Dalam di Rumah Sakit Advent Manado. Jurnal GIZIDO. 2016; 8(2):22-34.

18. Syamsiatun, N.H., Hadi, H., Julia, M. Hubungan Antara Status Gizi Awal dengan Status Pulang dan Lama Rawat Inap Apsien Dewasa di Rumah Sakit. Jurnal Gizi Klinik Indonesia. 2014; 1(1):27 -34 .

19. Budiningsari RD dan Hadi H. Pengaruh Perubahan Status Gizi Pasien Dewasa terhadap Lama Rawat Inap dan Biaya Rumah Sakit. Jurnal Gizi Klinik Indonesia. 2004; 1(1):35-44.

20. Entika RH. Hubungan Status Gizi dan Sindrom Metabolik dengan Kejadian Komplikasi Pasien Diabetes Melitus Tipe 2 Rawat Jalan di RSUD Dr. Moewardi. Skripsi. Surakarta: Program Studi IImu Gizi Fakultas IImu Kesehatan, Universitas Muhammadiyah Surakarta. 2017. 
21. Nurlindayanti E, Susetyowati, Probosuseno, Pangastuti R. Kecemasan dan Status Gizi Berhubungan dengan Lama Rawat Inap pada Pasien Jantung di RSUD Jenderal Ahmad Yani, Metro, Lampung. Jurnal Gizi dan Dietetik. 2015; 3 (2):98-104. 